\title{
URGENSI PENGELOLAAN ZAKAT TERHADAP PENINGKATAN PEREKONOMIAN MASYARAKAT
}

\author{
Basyirah Mustarin \\ Universitas Islam Negeri (UIN) Alauddin Makassar \\ Email: basyirahbabas@gmail.com
}

\begin{abstract}
Amil zalcat institution as zakat managers acting as a bridge between Muzakki with Mustahik in collecting zakat funds, then manage and distribute the zakat funds properly and appropriately targeted to Asnaf recipients of zakat mentioned in Al-Quran. The management of zakat funds professionally conducted by zalcat amil as well as on the mustahiq side guarantees the proper delivery of the mandate, can also help to alleviate the community from the very urgent poverty problem today. Zakat funds used to empower the poor and needy will productively seek the transformation of mustahiq that has been memetaforsa into muzakki can help and more useful for other mustahiq.
\end{abstract}

Keywords: Urgency, Management, Institute of amil zakat

\begin{abstract}
Abstrak
Lembaga amil zakat sebagai pengelola zakat yang bertindak sebagai jembatan penghubunga antara Muzakki dengan Mustahik dalam mengumpulkan dana zakat, kemudian mengelola serta mendistribusikan dana zakat tersebut secara benar dan tepat sasaran kepada para Asnaf penerima zakat yang telah disebutkan dalam Al-Quran. Pengelolaan dana zakat secara profesional yang dilakukan oleh lembaga amil zakat selain pada sisi mustahiq menjamin tersalurkannya amanah dengan tepat, juga dapat membantu mengentaskan masyarakat dari masalah kemiskinan yang amat urgen sekarang ini. Dana zakat yang dipergunakan memberdayakan kaum fakir dan miskin secara produktif akan mengupayakan terjadinya transformasi dari mustahiq yang telah bermetaforsa menjadi muzakki dapat membantu dan lebih bermanfaat lagi bagi para mustahiq lainnya.
\end{abstract}

Kata kunci : Urgensi, Pengelolaan, Lembaga amil zakat 


\section{PENDAHULUAN}

7 ekonomian yang berkembang dewasa ini menunjukkan bahwa ada masyarakat yang belum terpenuhi hak atas kebutuhan dasarnya L secara layak karena belum memperoleh pelayanan sosial dari pemerintah. Akibatnya masih ada masyarakat yang mengalami hambatan pelaksanaan fungsi sosial sehingga tidak dapat menjalani kehidupan secara layak dan bermartabat. Fakta ini merupakan hal yang sangat ironis, mengingat Indonesia adalah sebuah negara yang dikarunia kekayaan alam sebagaimana yang dinyatakan dalam Pasal 33 Undang-Undang Dasar Negara Republik Indonesia Tahun 1945.

Kondisi ini tidak termanfaatkan dengan baik, sehingga yang terjadi justru sebaliknya. Dapat disaksikan fenomena eksploitasi alam yang tidak terkendali oleh para oknum yang tidak bertanggung jawab. Hutan-hutan dibabat habis oleh pelaku-pelaku usaha yang tidak bertanggung jawab, sehingga menyebabkan kerugian negara yang mencapai 30 (tiga puluh) trilyun setiap tahunnya. Sumber daya alam lainnya seperti mineral dan barang tambang, juga tidak dapat dimanfaatkan sebesar-besarnya untuk kepentingan masyarakat, yang terjadi adalah menciptakan kesenjangan luar biasa besarnya. Keadaan tersebut membentuk kelompok masyarakat yang betul-betul kaya dan kelompok masyarakat miskin. Akibatnya muncullah kesenjangan yang luar biasa di tengahtengah masyarakat kita.

Kondisi tersebut merupakan potret dari kemiskinan struktural artinya kemiskinan turun temurun yang ada bukan disebabkan oleh lemahnya etos kerja melainkan disebabkan tidak memiliki keilmuan atau pendidikan yang cukup. Kemiskinan model ini sangat membahayakan kelangsungan hidup sebuah masyarakat, sehingga diperlukan adanya sebuah mekanisme yang mampu mengalirkan kekayaan yang dimiliki oleh masyarakat mampu (the have) kepada masyarakat yang tidak mampu (the have not), banyak akibat buruk yang dapat timbul karena adanya kemiskinan, terutama banyaknya terjadi kriminal di lingkungan tempat tinggal yang kawasannya agak kumuh dan kurang berpendidikan. Kemiskinan merupakan bahaya besar bagi umat manusia dan tidak sedikit umat yang jatuh keimanannya hanya karena kefakiran. Sebagaimana sabda Nabi yang menyatakan bahwa "kefakiran itu mendekati pada kekufuran".

Kefakiran terkadang mendorong seseorang melakukan tindakan- tindakan

yang tak dibenarkan agama. Kefakiran juga memaksanya untuk melakukan tindakan haram; seperti mencuri, mencopet, merampok, menipu, dan sebagainya. Problematika kemiskinan ini sebenarnya bukan masalah baru, sejak dahulu berbagai agama dan aliran filsafat mencoba memecahkannya untuk 
mengakhiri penderitaan kaum fakir akan tetapi masing-masing memiliki sikap yang berlainan terhadap kemiskinan.

Islam mengajarkan melalui Rasulullah SAW., untuk menanggulangi kemiskinan karena kemiskinan mengancam akidah umat dan menyebabkan timbulnya kekacauan kejahatan dan kebejatan moral dengan empat cara yakni:

(1) Bekerja dengan giat dan bersemangat.

(2) Keluarga yang lemah menjadi tanggung jawab keluarga yang kuat.

(3) Kewajiban membayar zakat.

(4) Ada jaminan pemerintah untuk keluarga yang tidak mampu.

Dari keempat hal tersebut, salah satunya tercantum perintah untuk membayar zakat yang harus dilakukan bagi setiap individu umat muslim.

Zakat merupakan salah satu rukun Islam yang bersifat normatif, menarik untuk diteliti dan dikaji dalam dua hal, pertama dari aspek yuridisnya yang menyangkut konsep hukum zakat dan kedua mengenai bagaimana pengelolaan dan pendayahgunaannya yang tetap berdasarkan dengan peraturan perundangundangan di Indonesia tepatnya sesuai dengan Undang-undang No.23 tahun $2011^{1}$. Secara normatif, ketentuan yang dirancang sesuai dengan ketentuan dan perkembangan pada saat pembuatannya dan merupakan sebuah karya hukum yang bernilai, akan tetapi untuk diberlakukan pada kondisi masyarakat yang sudah modern seperti sekarang ini, tidak proporsional lagi, mengingat keadaan yang sudah banyak mengalami perubahan dan perkembangan yang tentunya akan menimbulkan banyak masalah dalam penerapannya (Al-zuhaily. Hal tersebut dapat dilihat dari direvisinya Undang-undang pengelolaan zakat No.38 tahun 1999 menjadi Undang-undang No. 23 tahun 2011. Zakat merupakan hak bagi mustahik yang berfungsi untuk menolong sekaligus menghilangkan sifat iri, dengki dan hasad yang mungkin timbul dari kalangan mereka ketika melihat golongan kaya yang berkecukupan hidupnya.

Zakat sebagai salah satu rukun Islam, sebagaimana dalam rukun Islam lainnya (sholat, puasa, dan haji) tentunya didasarkan atas landasan hukum yang bersumber dari sumber utama hukum Islam, yaitu al-Quran dan hadits. Dalam alQuran kata zakat disebut dalam bentuk ma'rifat disebut sebanyak 30 kali, diantaranya 27 kali disebutkan dalam satu ayat bersama sholat, dan hanya kali disebutkan dalam konteks yang sama dengan sholat akan tetapi tidak didalam satu

1 Arfin Hamid,.Hukum Islam Perspektif Keindonesiaan, Sebuah Pengantar Memahami Realisasinya di Indonesia. (UmiToha Ukhuwah Grafika: Makassar.2011) 
ayat $^{2}$. Dilihat dari syariatnya, zakat bukanlah syariat baru yang hanya terdapat pada syariat Nabi Muhammad SAW, tetapi zakat merupakan bahagian dari syariat yang dibawa oleh para rasul terdahulu sebagai rangkaian dari ibadah fardu lainnya. Hal tersebut dialami pada masa nabi Ibrahim, Ismail, Isa. Namun pada masa Rasulullah SAW zakat telah disempurnakan baik dari segi pemasukanpengumpulan-dan penyaluran serta beberapa bagian yang harus dikeluarkan.

\section{PEMBAHASAN}

\section{A. Pengertian dan Ruang Lingkup Zakat}

Menurut Bahasa (etimologi), zakat berarti: suci, tumbuh; berkembang; kesuburan atau bertambah (HR. At-Tirmidzi) atau dapat pula berarti membersihkan atau mensucikan. Zakat berasal dari kata dasar zaka, yang berarti bertambah, subur, tidak cacat atau baik. Seseorang yang zaki berarti orang itu lebih banyak bersifat baik atau lebih banyak memiliki sifat-sifat sebagai orang baik $^{3}$.

Dinamakan zakat itu "zaka", karena harta itu berpotensi untuk bertambah dan tumbuh. Aktifitas berzakat dapat mengembangkan harta. Islam sangat menganjurkan setiap harta hendaknya dikembangkan dengan usaha dan kreatifitas. Islam mencela orang-orang yang hanya mendiamkan harta, padahal harta tersebut berpotensi berkembang secara maknawi. Makna "zaka" juga berarti tidak cacat atau baik. Artinya dengan berzakat maka harta tersebut dibersihkan dari hak mustahik yang terdapat dalam harta tersebut. Jiwa orang yang berzakat akan menjadi baik, karena hilang dari sifat kekikiran dan sebaiknya akan tumbuh solidaritas kasih sayang. Berzakat juga menjauhkan harta yang telah diambil zakatnya dari bahaya. Hati dan harta orang yang membayar zakat tersebut menjadi suci dan bersih. Orang yang telah bersih dan suci hatinya karena telah membersihkan hartanya dengan zakat maka orang-orang tersebut disebut "zaki".

Zakat menurut terminologi berarti, sejumlah harta tertentu yang diwajibkan oleh Allah SWT. Untuk diberikan kepada para mustahik yang telah disebutkan dalam Alquran. Zakat bisa juga berarti sejumlah harta yang diberikan untuk orang tertentu. Lafal zakat zakat dapat berarti sejumlah harta yang diambil dari harta orang yang berzakat. Syukri Ghozali mengemukakan bahwa zakat

${ }^{2}$ Fakhruddin, Fiqhi dan Managemen Zakat di Indonesia. (Malang, Universitas Islam Negeri Malang Pres, 2008). Hal:44.

${ }^{3}$ Yusuf Qardawi,..Hukum Zakat Studi Mengenai Status dan Filsafat Zakat Berdasarkan Alquran dan Hadits. (Litera AntarNusa.2011: Jakarta): Hal 34 
adalah bagian tertentu dari harta kekayaan yang diberikan seseorang sebagai hak Allah kepada yang berhak menerimanya antara lain fakir miskin, menurut ketentuan-ketentuan agama Islam. Adapun harta yang dibagi-bagikan itu namanya zaka, dan kata zakat artinya bertambah, suci, berubah karena dengan dikeluarkannya zakatnya harta itu diharapkan bertambah, suci, dan berberkah. ${ }^{4}$ Sedangkan menurut undang-undang No.23 Tahun 2011 tentang Pengelolaan Zakat pada bab I pasal 1 menyebutkan bahwa zakat adalah harta yang wajib dikeluarkan oleh seorang muslim atau badan usaha untuk diberikan kepada yang berhak menerimanya sesuai dengan syariat Islam. Dalam Alquran terdapat banyak ayat yang membahas masalah zakat. Banyaknya jumlah ayat tersebut menggambarkan dengan jelas bahwa zakat mempunyai kedudukan, fungsi dan peranan yang sangat penting. Berikut ini dikutipkan beberapa ayat yang menjelaskan tentang zakat. Berikut ini dikutipkan beberapa ayat al-quran yang menjelaskan tentang zakat.

1. QS. Al-Baqarah

a) Ayat 43

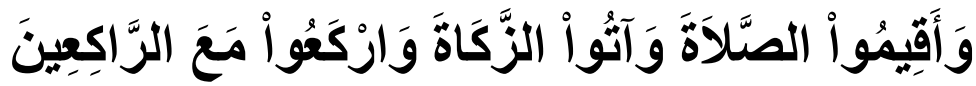

Dan dirikanlah shalat, tunaikanlah zakat dan ruku'lah beserta orang-orang yang ruku'

2. QS. Al-Taubah

a) Ayat 60

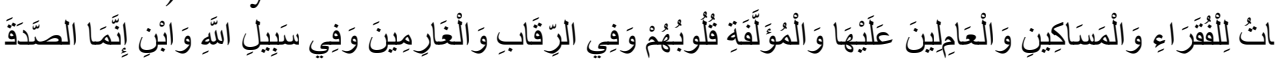

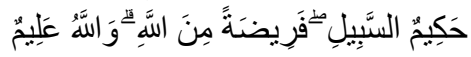

"Sesungguhnya zakat-zakat itu, hanyalah untuk orang-orang fakir, orangorang miskin, pengurus-pengurus zakat, Para mu'allaf yang dibujuk hatinya, untuk (memerdekakan) budak, orang-orang yang berhutang, untuk jalan Allah dan untuk mereka yuang sedang dalam perjalanan, sebagai suatu ketetapan yang diwajibkan Allah, dan Allah Maha mengetahui lagi Maha Bijaksana.

${ }^{4}$ Ahmad Azhar.1997.Hukum Zakat, Edisi Pertama. Jogyakarta Hal : 35 
b) Ayat 103

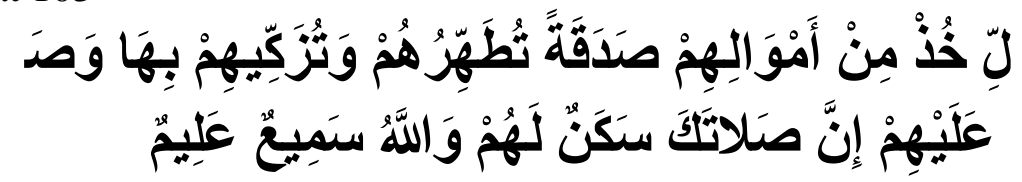

"ambillah zakat dari sebagian harta mereka, dengan zakat itu kamu membersihkan[658] dan mensucikan[659] mereka dan mendoalah untuk mereka. Sesungguhnya doa kamu itu (menjadi) ketenteraman jiwa bagi mereka. dan Allah Maha mendengar lagi Maha mengetahui."

3. QS. al-Mu'minum, ayat $1-4$

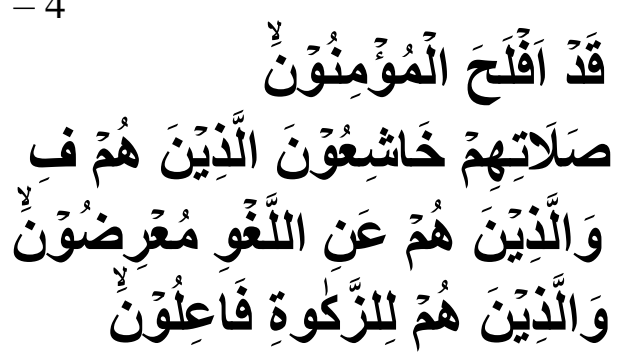

1. Sesungguhnya beruntunglah orang-orang yang beriman,

2. (yaitu) orang-orang yang khusyu' dalam sembahyangnya,

3. dan orang-orang yang menjauhkan diri dari (perbuatan dan perkataan) yang tiada berguna,

4. dan orang-orang yang menunaikan zakat,

Zakat secara umum terdiri dua macam, yaitu: pertama, zakat yang berhubungan dengan jiwa manusia (Zakat Nafs/Badan), yaitu zakat fitrah dan kedua,dan zakat yang berhubungan harta (zakat mal).

Dalam mengeluarkan zakat ada beberapa persyaratan yang harus dipenuhi, di mana persyaratan tersebut telah ditentukan secara syariat Islam. Persyaratan yang dimaksudkan adalah syarat yang harus dipenuhi dari sisi wajib zakat (orang yang memberikan zakat) dan dari sisi syarat harta yang dapat dikeluarkan zakatnya. Syarat ini dibagi menjadi dua, yaitu syarat wajib dan syarat sah. Adapun syarat wajib zakat adalah:

1. Merdeka; Seorang budak tidak dikenai kewajiban membayar zakat, karena dia tidak memiliki sesuatu apapun. Semua miliknya adalah milik tuanya.

2. Islam; Seorang non muslim tidak wajib membayar zakat. Adapun untuk mereka yang murtad, terdapat perbedaan pendapat. Menurut Iman Syafii orang murtad diwajibkan membayar zakat terhadap hartanya sebelum dia murtad. Sedangkan menurut Imam Hanafi, seorang murtad tidak dikenai 
zakat terhadap hartanya karena perbuatan riddah-nya (berpaling dari agama Islam) telah menggugurkan kewajiban tersebut.

3. Baligh dan berakal; Anak kecil dan orang gila tidak dikenai zakat pada hartanya, karena keduanya tidak dikenai kitab perintah.

4. Harta tersebut merupakan harta yang memang wajib dizakati. Seperti naqdaini (emas dan perak) termasuk juga al-auraq al-naqdiyah (suratsurat berharga), barang tambang dan barang temuan (rikaz), barang dagangan, tanaman-tanaman dan buah-buahan, serta hewan ternak.

5. Harta tersebut telah mencapai nisab (ukuran jumlah).

6. Harta tersebut adalah milik penuh (al-milk al-tam). Dalam hal ini, harta tersebut berada di bawah kontrol dan di dalam kekuasaan pemiliknya.

7. Telah berlalu satu tahun atau cukup haul (ukuran waktu, masa).

Haul adalah perputaran harta satu nisab dalam 12 bulan qamariyah. Apabila terdapat kesulitan akuntansi karena biasanya angaran dibuat berdasarkan tahun syamsiah, maka boleh dikalkulasikan berdasarkan tahun syamsiyah dengan penambahan volume zakat yang wajib dibayar, dari 2,5\% menjadi 2,575\% sebagai akibat kelebihan hari bulan syamsyiah dari bulan qamariyah.

8. Tidak adanya hutang.

9. Melebihi kebutuhan dasar atau pokok.Barang-barang yang dimiliki untuk kebutuhan pokok, seperti rumah pemukiman, alat-alat kerajinan, alat-alat industri, sarana transportasi dan angkutan, seperti mobil dan perabotan rumah tangga, tidak dikenakan zakat. Demikian juga uang simpanan yang dicadangkan untuk melunasi hutang, tidak diwajibkan zakat, karena seorang kreditor memerlukan uang yang ada ditangannya untuk melepaskan dirinya dari cengkeraman hutang.

10. Harta tersebut harus didapatkan dengan cara yang baik dan halal.

11. Berkembang; Pengertian berkembang tersebut terbagi menjadi dua, yaitu pertama, bertambah secara kongkrit dan kedua, bertambah secara tidak kongkrit. Berkembang secara kongkret adalah bertambah akibat pembiakan dan perdagangan dan sejenisnya, sedangkan berkembang tidak secara kongkret adalah kekayaan itu berpotensi berkembang baik berada ditangannya maupun ditangan orang lain atas namanya. ${ }^{5}$

Sedangkan Syarat sahnya zakat adalah sebagai berikut:

${ }^{5}$ Diakses tanggal November 2017

http://www.google.com/\#psj=1\&q=pengaruh+dana+zakat+produktif 
1. Adanya niat muzakki (orang yang mengeluarkan zakat).

2. Pengalihan kepemilikan dari muzakki ke mustahik (orang yang menerima zakat).

\section{B. Manfaat dan Hikmah Zakat}

Zakat memiliki keutamaan besar bagi orang yang menunaikannnya. Pengaruh-pengaruh zakat sangat besar dan berguna bagi individu dan umat, karena zakat adalah ibadah untuk Allah yaitu:

1. Mendapat kedudukan tinggi; zakat dapat meningkatkan kedudukan seorang hamba hingga menjadi robbani. Manusia akan mencapai tingkatan ini bila telah terlepas dari kecintaan terhadap dunia (khususnya cinta harta) dan menjadi hamba Allah semata, bukan hamba dinar atau dirham. Ini seperti yang disampaikan nabi SAW:

2. Terapi penyakit cinta harta ; cinta harta adalah penyakit berbahaya dan kronis. Secara fitnah, manusia diciptakan sangat mencintai harta. Manusia tidak bisa terlepas dari cinta harta yang membuatnya menghuni dasar dari neraka jahanam kecuali dengan mengeluarkan zakat setiap tahunnya.

Adapun Hikmah dari mengeluarkan zakat ialah sebagai berikut:

1. Membersihkan jiwa dari penyakit kikir bakhil bila penyakit ini menguasai jiwa seseorang, ia tidak mampu melepaskan diri darinya. Penyakit ini mendatangkan murka dan kebencian Allah. Harta itu tidak hari kiamat kelak berubah menjadi lembaran-lembaran tempat pemiliknya di panggang di neraka jahanam.

2. Bahagia dunia dan akhirat; adalah berupa hartanya bertambah dan berkah, sebab orang yang menginfakkan sebagian hartanya akan dilipat gandakan olah Allah SWT. Di samping kebahagian dunia, zakat juga sebagai obat untuk orang sakit serta mendatangkan kesehatan dan keselamatan. Adapun kebahagian akhirat adalah berupa penghapusan keburukan dan penambahan kebaikan, disamping itu zakat merupakan jalan menuju ampunan dan keberuntungan meraih surga. Bahkan, untuk mencapai tingkat tertinggi di surga.

3. Terhindar dari dan dendam orang fakir; iri dan dengki orang fakir ini bisa berubah menjadi sikap permusuhan, berusaha untuk mencuri dan merampas hartanya, bahkan saja membunuh dan mencuri hartanya. Namun bila orang kaya bersikap lemah lembut terhadap orang miskin, berbagi dengan orang-oranmg fakir, menatap anak-anak yatim dan janda dengan pandangan kasih sayang dan membantu mereka yang memerlukan 
uluran tangan, sikap ini akan membuatnya dicintai orang-orang fakir. Ia pun merasa aman, tenang, dan tentram.

4. Doa untuk muzakki dari orang yang menerima zakat; dianjurkan mendoakan orang yang memberi zakat dengan mengucapkan hal yang baik agar ia dilapangkan rezkinya serta selamat dunia akhirat. ${ }^{6}$

Dari banyaknya manfaat dan hikmah zakat yang telah dipaparkan tersebut maka dapatlah kita lihat dengan jelas betapa banyaknya manfaat yang dapat kita terima dari baik untuk diri kita sendiri maupun untuk orang lain.

\section{Pengelolaan Zakat Di Indonesia}

Badan Amil Zakat adalah organisasi pengelolaan zakat yang dibentuk oleh pemerintah dengan kepengurusan terdiri atas unsur masyarakat dan pemerintah. Badan Amil Zakat yang dibentuk di tingkat nasional disebut Badan Amil Zakat Nasional disingkat BAZNAS dan yang dibentuk di daerah disebut Badan Amil Zakat. Dalam hal kedudukan lembaga amil zakat (LAZ) sebagai pengelola zakat berbeda dengan Badan Amil Zakat (BAZ) yang dibentuk oleh negara. LAZ merupakan organisasi yang tumbuh atas dasar inspirasi masyarakat yang memiliki tugas membantu pengumpu lan, pendistribusian, dan pendayagunaan zakat.

\section{Potensi Zakat Pada Sektor ekonomi}

Sektor dalam perekonomian merupakan objek penting dalam pembahasan zakat. Melalui sektor ini dapat dijadikan sebagai barometer kemajuan dan peningkatan perekonomian suatu negara. Dengan kata lain zakat dapat berperan penting dalam pengurangan dan penumpasan masyarakat miskin, dengan dilakukannya pengelolaan dan penggunaan dana zakat secara tertuju dan merata maka perekonomian yang meningkat pastilah akan tercapai, dan masyarakat yang miskin akan terkikis dengan sendirinya.

Suatu pembangunan dapat dikatakan berhasil jika prosesnya mampu meningkatkan perekonomian masyarakat jangka panjang. Perekonomian tersebut tercermin dalam kualitas perekonomian masyarakat yang prima, tingkat pendidikan yang memadai, dibarengi tingkat pendapatan perkapita yang tinggi

Kewajiban mengeluarkan zakat mempunyai landasan kuat sebagai pencapaian negara bertaraf ekonomi tinggi untuk mewujudkan perekonomian bagi

\footnotetext{
${ }^{6}$ Ali Mohammad Daud, 2012, Hukum Islam: Pengantar Ilmu Hukum dan Tata Hukum Islam di Indonesia. (RajaGrafindo Persada: Jakarta )Hal.150-151
} 
setiap orang yang membutuhkan, yaitu dalam bidang pangan, sandang, perumahan, dan kebutuhan hidup lainnya. ${ }^{7}$

Ketentuan yang ditetapkan Allah Swt pada semua aspek kehidupan manusia pada umumnya memiliki dua fungsi utama yang memberikan manfaat bagi individu (nafs) dan kolektif (jama'i). Demikian pula halnya dengan sistem zakat dalam ekonomi Islam yang befungsi sebagai alat ibadah bagi orang yang membayar zakat (muzakki) yang memberikan kemanfaatan individu (nafs), dan berfungsi sebagai penggerak ekonomi bagi orang-orang dilingkungan yang menjalankan sistem zakat ini, yang memberikan kemanfaatan kolektif (jama'i).

Meski demikian, undang-undang ini telah merintis upaya pemberian insentif bagi wajib zakat dengan menjadikan zakat sebagai pengurang pajak. Apabila suatu masyarakat sadar untuk berzakat, maka zakat tersebut akan berdampak dan memiliki pengaruh terhadap perekonomian suatu negara. Adapun bentuk zakat dalam peningkatan ekonomi yang lebih terperinci akan dibahas pada bab berikutnya.

\section{E. Arah Hasil Pengelolaan Zakat Terhadap Peningkatan Ekonomi}

Dari hasil penelitian tentang keempat program besar pendayagunaan hasil pengumpulan zakat yang diterima oleh lembaga amil zakat, dibagi dalam dua pola besar yaitu:

1.) Konsumtif, program penyaluran hasil pengumpulan zakat secara konsumtif diberikan untuk memenuhi kebutuhan dasar ekonomi para mustahik melalui pemberian langsung, maupun lembaga-lembaga yang mengelola fakir miskin, panti asuhan, maupun tempat-tempat ibadah yang mendistribusikan zakat kepada masyarakat. Pemberdayaan zakat secara konsumtif dibagi dalam dua bagian yaitu:

a. Konsumtif tradisional, zakat dibagikan kepada mustahik secara langsung untuk konsumsi sehari-hari, seperti pembagian zakat fitrah berupa beras dan uang kepada fakir miskin setiap idul fitri atau pembagian zakat maal secara langsung oleh para muzakki di daerah binaan lembaga amil zakat yang sangat membutuhkan karena ketiadaan pangan atau mengalami musibah.

b. Konsumtif kreatif, zakat yang diwujudkan dalam bentuk barang komsumtif dan digunakan untuk orang miskin untuk mengatasi

\footnotetext{
${ }^{7}$ Monzer Kahf. 1995. Ekonomi Islam Telaah Terhadap Fungsi Sistem Ekonomi Islam. Pustaka Pleajar: Yogyakarta. Hal:88.
} 
permasalahan sosial ekonomi yang dihadapinya. Bantuan tersebut antara lain berupa alat perlengkapan sekolah dan beasiswa untuk para pelajar, bantuan perlengkapan ibadah seperti sarung dan mukena, obat-obatan yang disediakan pada Posyandu yang ada di daerah binaan, dan lain-lain

2.) Produktif, program penyaluran hasil pengumpulan zakat secara produktif dilakukan melalui program bantuan modal usaha untuk masyarakat miskin, pendidikan gratis dalam bentuk beasiswa, dan pelayanan kesehatan gratis. Penyaluran dana zakat dapat digolongkan dalam dua golongan yaitu:

a. Produktif kompensional, zakat diberikan dalam bentuk barang produktif, dimana dengan menggunakan barang tersebut, para mustahiq dapat menciptakan suatu usaha. seperti pemberian mesin jahit, pembekalan skill.

b. Produktif kreatif. Zakat diwujudkan dalam bentuk pemberian modal bergulir baik permodalan berupa pinjaman maupun secara cuma-cuma diberikan kepada masyarakat, pembuatan fasilitas sosial seperti membangun pos sehat, posyandu, klinik pengobatan gratis, sebagainya. Dana zakat yang diterima terkumpul dialihkan kedalam 4 program besar yaitu:

1. Program pendidikan

2. Program kesehatan

3. Program kewirausahaan

4. Program peduli lingkungan sehat

Undang-undang No.23 Tahun 2011 tentang pengelolaan zakat, memberi kebebasan kepada lembaga pengumpul zakat untuk mendayahgunakan dana zakat yang terkumpul demi mewujudkan perekonomian masyarakat dan menanggulangi kemiskinan, dengan syarat pengelolaan yang dilakukan oleh lembaga tersebut sesuai dengan UU No.23 Tahun 2011 tentang pengelolaan zakat Pasal 2 dan pasal 25 yaitu:

Pasal 2: Pengelolaan zakat berasaskan:

a. syariat Islam;

b. amanah;

c. kemanfaatan;

d. keadilan;

e. kepastian hukum;

f. terintegrasi; dan

g. akuntabilitas. 
Pasal 25 : Zakat wajib didistribusikan kepada mustahik sesuai dengan syariat Islam

Pengelolaan zakat sangat penting dilakukan secara profesional agar menjadi sumber dana yang dapat dimanfaatkan bagi perekonomian masyarakat, terutama untuk mengentaskan masyarakat dari kemiskinan dan menghilangkan kesenjangan sosial dan dapat dipertanggungjawabkan yang kepada muzakki dan pemerintah. Dalam hal ini pemerintah berkewajiban memberikan perlindungan, pembinaan dan pelayanan kepada muzakki, mustahik dan pengelola zakat. Untuk itu, maka dalam pengelolaan zakat harus berdasarkan iman dan takwa, agar dapat mewujudkan keadilan sosial, kemaslahatan, keterbukaan dan kepastian hukum. Adapun tujuan pengelolaan zakat meliputi:

1. Meningkatkan kesadaran masyarakat dalam menunaikan dan dalam pelayanan ibadah zakat sesuai dengan tuntunan agama.

2. Meningkatkan fungsi dan peranan pranata keagamaan dalam upaya mewujudkan perekonomian masyarakat dan keadilan sosial.

3. Meningkatkan hasil guna dan daya guna zakat.

\section{PENUTUP}

lembaga pengelola zakat besar yang memiliki puluhan unit cabang kerja yang tersebar diseluruh wilayah Indonesia contohnya seperti Rumah Zakat dan Dompet Duafa, dinilai sudah cukup menjalankan fungsinya dalam menghapus kemiskinan dan meningkatkan perekonomian masyarakat yang ada di Makassar. Namun, perbaikan yang dilakukan lembaga amil zakat yang besar masih terfokus hanya sebatas pada daerah-daerah binaan yang didirikan oleh masing-masing lembaga tersebut. Perbaikan ekonomi yang telah dilakukan dianggap sudah cukup tepat, sebab telah mewakili wilayah bagian Kota Makassar yang memiliki penduduk miskin yang cukup besar. Adapun lembaga amil zakat yang kecil (lembaga yang tidak memiliki cabang pada wilayah indonesia) masih dinilai belum mampu menangani penghapusan kasus kemiskinan yang ada di wilayah Makassar sebab jumlah dana yang diterima pada lembaga tersebut sangat sedikit. Upaya Rumah Zakat dan Dompet Duafa dalam mengelola zakat terbagi kedalam empat bidang utama, yaitu : bidang pendidikan dengan pemberian beasiswa dan perlengkapan sekolah, bidang perekonomian dengan pemberian modal usaha Cuma-Cuma dan pembekalan keterampilan kerja, bidang kesehatan dengan penyediaan klinik gratis dan pengobatan Cuma-Cuma, dan bidang pelestarian lingkungan dengan penanaman halaman rumah masyarakat dengan tanaman yang dapat dikonsumsi. 


\section{DAFTAR PUSTAKA}

Al-zuhayly, Wahibah.(2008). Zakat dan Kajian Berbagai Mazhab. Remaja Rosdakarya: Bandung.

Aflah, Noor . (2009). Arsitektur zakat indonesia. UI Press: Jakarta.

Aflah, Noor . (2006). Zakat dan Peran Negara. Sinar Pustaka: Jakarta.

Afifi, Agus.(2010). Kekuatan zakat, hidup berkah rejeki melimpah. . Niaga swadaya: Jakarta.

Ali Muhammad, Nurdin. (2006). Zakat Sebagai Instrumen Dalam Kebijakan Fiskal. Raja Grafindo Persada: Jakarta.

Ali Mohammad, Daud, (2012), Hukum Islam: Pengantar Ilmu Hukum dan Tata Hukum Islam di Indonesia. RajaGrafindo Persada: Jakarta

Ali bin al-Mursyaiqih Khalid. (2010). Zakat Kontemporer. Embun Litera Publishing: Jakarta.

Arikunto, Suharsimi. (2006). Prosedur Penelitian Suatu Pendekatan Praktik. Rineka Cipta: Jakarta.

As-siddiqi Hasbi. (2009). Pedoman Zakat. Pustaka Reski Putra: Semarang.

As-Siddiqie, Hasbi.(2008). Pengantar Hukum Islam. Bulan Bintang: Jakarta.

Didin, Hafidhuddin. (2008). The Power Of Zakat study perbandingan pengelolaan zakat AsiaTenggara. UIN Pres Malang: Malang.

Didin,Hanifuddin.(2008). Zakat dalam Perekonomian Modern. Gema Insani: Jakarta.

Djasuli, M.A.(2006). Fiqhi Siasyah, Implementasi Kemaslahatan Umat dalam Rambu-rambu Syari'ah(edisi revisi). Prenada media: Bandung.

Hamid, Arfin.(2006). Hukum Zakat Pengembangan dan Pendayahgunaan, Umitoha Ukhuwah Grafika: Makassar.

Hamid, Arfin. (2011). Hukum Islam Perspektif Keindonesiaan, Sebuah Pengantar Memahami Realisasinya di Indonesia. UmiToha Ukhuwah Grafika: Makassar.

Muin, Rahmawati. 2011. Manajemen Zakat. Alauddin University Press: Makassar.

Qardawi, Yusuf. 2011. Hukum Zakat Studi Mengenai Status dan Filsafat Zakat Berdasarkan Alquran dan Hadits. Litera AntarNusa: Jakarta.

Sudirman. 2007. Zakat dalam Pusaran Arus Moderenitas. UIN Malang Press: Malang.

Sari, Elsi Kartika. 2006. Pengantar Hukum Zakat dan Wakaf. Grasindo: Jakarta

Sohrah. 2012. Zakat dan Kebijakan Fiskal Meretas Akar-akar Kemiskinan. Universitas Islam Negeri Press: Makassar. 